\title{
With Corona Virus, We Get Sick; With the Weapon of Science and Engineering, We Fight Back?
}

Qinglong Jiang, ${ }^{*}$ Zhanhu Guo, ${ }^{3}$ Guang Yang, ${ }^{4}$ Evan Wujick ${ }^{5}$ and Hongbo $\mathrm{Gu}^{2 *}$

Accepted 8 March 2020 DOI: $10.30919 /$ es8d916

Wuhan, a major city with a population of more than 15 million people, was quarantined due to the outbreak of coronavirus disease (COVID-19) on January $23^{\text {rd }}$, 2020. Just a few days later, other seventeen cities in Hubei Province were also quarantined. One month later, over 3,100 people, including medical personnel, had died from COVID-19 and 80,000 more people were infected in China alone. Unfortunately, COVID19 has spread to over 85 countries in 6 continents within a month: South Korea, Japan, Italy, USA, Iran, Australia, Algeria, Brazil, etc. The list of quarantined cities grows, and includes Lombardie in Italy and Daegu in South Korea, and the number of cases grows.
Seven years ago, in the Middle East, Middle East Respiratory Syndrome (MERS-CoV), which is similar to the corona virus, spread over fourteen countries, killed over 858 people and affected another 2,494 people from all over the world. ${ }^{1,2}$ Seventeen years ago, in Guangdong, Severe Acute Respiratory Syndrome (SARS-CoV) killed over 774 people and affected over 8,098 cases all over the world. ${ }^{3,4}$

Corona virus is only one type of the viruses that threatens the human being and other livings.

44 years ago, 1976 in Africa, Ebola virus affected over 35, 000 cases and more than half of them were killed since then. ${ }^{5}$ 100 years ago, Spanish flu spread to 6 continents and over 20

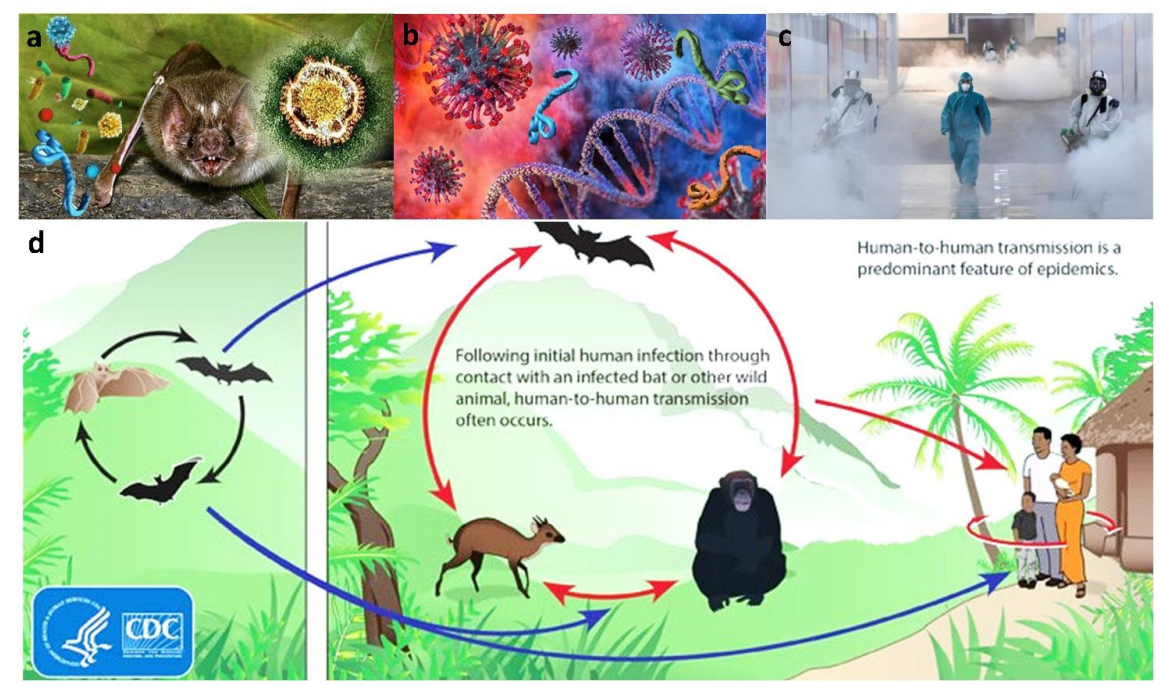

Fig. 1 (a) Bat is a known host for lots of viruses including Corona viruses and Ebola virus; (b) viruses are a small infectious agent that replicates only inside the living cells of an organism carrying DNA, RNA or as simple as only protein; (c) disinfection; (d) Corona and Ebola viruses ecology and transmission. ${ }^{8-11}$ (Credit: Centers for Disease Control and Prevention)

\footnotetext{
${ }^{1}$ University of Arkansas, Department of Chemistry and Physics, Pine Bluff, Arkansas 71601, USA

${ }^{2}$ School of Chemical Science and Engineering, Tongji University, Shanghai 200092, China

${ }^{3}$ Integrated Composites Laboratory (ICL), Department of Chemical \& Biomolecular Engineering, University of Tennessee, Knoxville, TN 37996 USA

${ }^{4}$ Department of Biomedical Engineering, Huazhong University of Science and Technology, Wuhan 430074, China

${ }^{5}$ Materials Engineering and Nanosensor [MEAN] Laboratory, Department of Chemical and Biological Engineering, The University of Alabama, Tuscaloosa, 35487-0203 USA

*E-mail: jiangq@uapb.edu (Q.Jiang); hongbogu2014@tongji.edu.cn (H. B. Gu);
} 


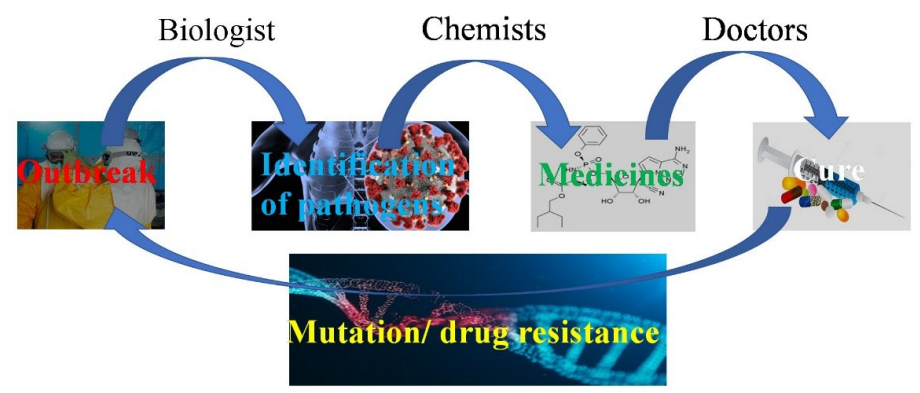

Fig. 2 Cycle of the battle between human and pathogens.

million got killed worldwide.

With the threaten of epidemic diseases, no individual and no country can stay away.

Of course, this is not the end of the list: Marburg virus, Lassa fever virus, Rift Valley fever virus, Crimean-Congo hemorrhagic fever virus, Arenavirus and Hantavirus, et al.

Scary enough?

Beside the viruses, the list of bacteria won't be shorter. The fear of black plague in the dark age, which wiped off half the population in Europe, is still here even after 600 years. Almost all of these are classified as Biosafety Level 4 (BSL-4) pathogens and must be handled in special facilities designed to contain them safely. And, there's no end for these lists: as the ice sheet in Antarctica and Permafrost melting, more ancient and unknown devils will be released. ${ }^{6,7}$

Bats, existing over 50 million years, have much longer history than human being on our planet. Most of the outbreaks mentioned above were related to bats, the host for lots of fetal viruses such as Corona virus for current outbreak, Ebola virus in 1976, Rabies virus for centuries, Hanta virus, Nipah virus and more (Figs. 1(a\&b)). It is the human who broke the balance of ecology (Fig. 1(d)), which backfired on ourselves.

Fortunately, with the weapon of Science and Engineering, we could strongly fight back. ${ }^{12-16}$ The advances in modern medicine, biology, chemistry, physics, civil engineering, medical instrument engineering and so on, are improving our life tremendously. For example, as shown in Fig. 2, when a coronavirus outbreak occurred, the biologists and chemists would start the identification of pathogens. They tried to develop the new drugs to fight the corona virus. During these processes, the bio-engineering and chemical engineering are play the important roles. After getting the medicine done, the doctors would applied the drugs to cure the patients. Meanwhile, the scientists also need to pay attention to the possible mutation of corona virus and continue to the development of novel medicine and vaccine. Eventually, the virus has been limited.

No matter the bats, viruses, bacteria or other forms of life, struggling to survive existed in the evolution, are the same case as the human being.

So far, the COVID-19 is not only a problem for China, but also for all human beings to face together. The scientists from all of the world start to work together to explore the molecular structures of COVID-19, its characteristics, and corresponding clinical medicine and vaccine. With the help of Science and Engineering as well as the efforts of all mankind, we can defeat the COVID-19.

Respect the life, Restore the balance, ${ }^{17}$ Reform the future.

\section{References}

1. www.who.int/csr/don/31-october-2019-mers-the-united-arab-emirates/zh/.

2. Z. A. Memish, A. Zumla, R. F. Alhakeem, A. Assiri, A. Turkestani, K. D. Al Harby, M. Alyemni, K. Dhafar, P. Gautret, M. Barbeschi, B. McCloskey, D. Heymann, A. A. Al Rabeeah and J. A. Al-Tawfiq. Lancet, 2014, 383, $2073-$ 2082.

3. www.who.int/csr/sars/country/table2004_04_21/en/.

4. S. Perlman and A. A. Dandekar, Nat. Rev. Immunol., 2005, 5, 917-927.

5. www.who.int/csr/disease/ebola/en/.

6. M. Legendre, J. Bartoli, L. Shmakova, S. Jeudy, K. Labadie, A. Adrait, M. Lescot, O. Poirot, L. Bertaux, C. Bruley, Y. Couté, E. Rivkina, C. Abergel and J. Claverie, Proc. Natl. Acad. Sci., 2014, 111, 4274-4279.

7. S. L. Bernard, A. Stéphane, R. Catherine, J. Liang, L. de Xavier, D. Michel, Richard Birtles, J. Claverie and R. Didier, Science, 2003, 299, 2033.

8. www.cdc.gov/vhf/ebola/resources/virus-ecology-fr.html.

9. www.bbc.com/zhongwen/simp/science-51382284.

10. www.taiwandaily.net.

11. https://news.rthk.hk/rthk/ch/component/k2/1509644-20200220.htm.

12. C. Liu, Q. Jiang, Z. Guo, N. Lu and M. Mortazavi, NanoScience: Nanomaterial, Nanotechnology and Applications, Knoxville: Engineered Science Publisher, 2019.

13. Z. W. K. Low, Z. Li, C. Owh, P. L. Chee, E. Ye, K. Dan, S. Y. Chan, D. J. Young and X. J. Loh, Biomater. Sci-UK. 2020, 8, 776-797.

14. H. S. Kim, X. Sun, J.H. Lee, H.W. Kim, X. Fu and K. W. Leong, Adv. Drug Deliver. R., 2019, 146, 209-239.

15. H. Zhang, K. Hippalgaonkar, T. Buonassisi, O. M. Løvvik, E. Sagvolden and D. Ding, ES Energy Environ., 2018, 2, 1-8.

16. J. Zhao, L. Wu, C. Zhang, B. Zeng, Y. Lv, Z. Li, Q. Jiang and Z. Guo, J. Mater. Chem. C, 2017, 5, 3903-3907.

17. Q. Jiang, M. Mortazavi, J. Wang, Y. Liu, Z. Wang, W. Yu, Z. Guo and B. Cao, ES Energy Environ., 2018, 1, 1-3.

Publisher's Note Engineered Science Publisher remains neutral with regard to jurisdictional claims in published maps and institutional affiliations. 